\title{
Lactobacillus gastricus sp. nov., Lactobacillus antri sp. nov., Lactobacillus kalixensis sp. nov. and Lactobacillus ultunensis sp. nov., isolated from human stomach mucosa
}

\author{
Correspondence \\ Stefan Roos \\ stefan.roos@mikrob.slu.se
}

\author{
Stefan Roos, ${ }^{1}$ Lars Engstrand ${ }^{2}$ and Hans Jonsson ${ }^{1}$ \\ 'Department of Microbiology, Swedish University of Agricultural Sciences, Box 7025, \\ SE-750 07 Uppsala, Sweden \\ ${ }^{2}$ Swedish Institute for Infectious Disease Control, SE-171 82 Solna, Sweden
}

\begin{abstract}
In an attempt to study the composition of the Lactobacillus flora from mucosa of human stomach, $16 \mathrm{~S}$ rRNA gene sequences of 129 isolates were analysed. For 15 of these, the results differed significantly from known sequences, and additional tests were performed to determine whether these isolates represented as yet unrecognized species. Phenotypic and genetic characteristics revealed that these isolates represented four novel Lactobacillus species. Two belong to the Lactobacillus reuteri and the other two to the Lactobacillus delbrueckii subgroup of Lactobacillus. The names Lactobacillus gastricus sp. nov., Lactobacillus antri sp. nov., Lactobacillus kalixensis sp. nov. and Lactobacillus ultunensis sp. nov. are proposed, with the respective type strains $\mathrm{K} \times 156 \mathrm{~A} 7^{\top}\left(=\mathrm{LMG} 22113^{\top}=\mathrm{DSM} 16045^{\top}=\right.$ CCUG $\left.48454^{\top}\right), \mathrm{K} \times 146 \mathrm{~A} 4^{\top}(=\mathrm{LMG}$ $22111^{\top}=\mathrm{DSM} 16041^{\top}=$ CCUG $\left.48456^{\top}\right), \mathrm{Kx} 127 \mathrm{~A} 2^{\top}\left(=\mathrm{LMG} 22115^{\top}=\mathrm{DSM} 16043^{\top}=\mathrm{CCUG}\right.$ $\left.48459^{\top}\right)$ and $\mathrm{Kx} 146 C 1^{\top}$ (=LMG $22117^{\top}=$ DSM $16047^{\top}=$ CCUG $\left.48460^{\top}\right)$.
\end{abstract}

In a study of the Lactobacillus flora of the human stomach, the almost complete 16S rRNA gene sequences of 129 isolates from this environment were analysed. For 15 of these isolates, the results differed significantly from known sequences and additional tests were performed to determine whether these isolates represented novel Lactobacillus species.

The strains were isolated from human gastric mucosa obtained from healthy individuals from Kalix, a town in northern Sweden. Primary isolates were produced by spreading homogenates of biopsies from both the antrum and the corpus region of the stomach on Rogosa agar (Merck). The plates were incubated for 3 days in anaerobic jars under a $\mathrm{CO}_{2}+\mathrm{N}_{2}$ atmosphere (GasPak System, BBL) at $37^{\circ} \mathrm{C}$. All further cultivation was performed at $37^{\circ} \mathrm{C}$ in anaerobic jars on MRS agar or in MRS broth (Oxoid) if not otherwise stated. Strains $\mathrm{Kx} 127 \mathrm{~A} 2^{\mathrm{T}}\left(=\mathrm{LMG} 22115^{\mathrm{T}}=\right.$ DSM $\quad 16043^{\mathrm{T}}=$ CCUG $\left.\quad 48459^{\mathrm{T}}\right), \quad \mathrm{Kx} 146 \mathrm{~A} 4^{\mathrm{T}} \quad(=\mathrm{LMG}$ $22111^{\mathrm{T}}=$ DSM $\quad 16041^{\mathrm{T}}=$ CCUG $\left.\quad 48456^{\mathrm{T}}\right), \quad \mathrm{Kx}^{2} 146 \mathrm{C1}^{\mathrm{T}}$

\footnotetext{
Published online ahead of print on 20 August 2004 as DOI 10.1099/ ijs.0.63083-0.

The GenBank/EMBL/DDBJ accession numbers for the 16S rRNA gene sequences of Lactobacillus gastricus $\mathrm{Kx} 156 \mathrm{~A} 7^{\top}$, Lactobacillus antri $\mathrm{K} \times 146 \mathrm{~A} 4^{\top}$, Lactobacillus kalixensis $\mathrm{K} \times 127 \mathrm{~A} 2^{\top}$ and Lactobacillus ultunensis $\mathrm{Kx} 146 \mathrm{C} 1^{\top}$ are AY253658, AY253659, AY253657 and AY253660, respectively.
}

$\left(=\right.$ LMG $22117^{\mathrm{T}}=$ DSM $16047^{\mathrm{T}}=$ CCUG $\left.48460^{\mathrm{T}}\right), \mathrm{Kx} 146 \mathrm{C} 2$ $(=$ LMG $22489=$ DSM $16044=$ CCUG 48458$), \mathrm{Kx}^{2} 56 \mathrm{~A}^{\mathrm{T}}$ $\left(=\mathrm{LMG} 22113^{\mathrm{T}}=\right.$ DSM $16045^{\mathrm{T}}=$ CCUG $\left.48454^{\mathrm{T}}\right), \mathrm{Kx} 293 \mathrm{C} 1$ (=LMG $22490=$ DSM $16048=$ CCUG 48461), Kx293C4 $(=$ LMG $22488=$ DSM $16046=$ CCUG 48455) and Kx329A2 ( =LMG 22112=DSM $16042=$ CCUG 48457) have been deposited with the BCCM, DSMZ and CCUG.

Bacterial DNA was isolated using the DNeasy Tissue kit (Qiagen). The almost complete 16S rRNA gene sequences for the strains were amplified by PCR with domain Bacteriaspecific primers (Weizenegger et al., 1992). The resulting PCR products were purified by using the Qiagen PCR purification kit. The first part (about $500 \mathrm{bp}$ ) of the purified fragments was sequenced according to standard methods. For some strains, the whole fragment was sequenced. The primers used for amplification, together with additional internal primers, were used for sequencing of the PCR products. The sequences obtained from the isolates were used for searches in the GenBank database and levels of DNA similarity were analysed with the SIMILARITY MATRIX tool at Ribosomal Database Project II (http://rdp.cme. msu.edu/html). Sequences representing the closest matches were retrieved and then aligned using the CLUSTAL $\mathrm{W}$ program (Thompson et al., 1994). For all sequences, approximately $1450 \mathrm{nt}$ were used. A distance matrix was calculated using the DNADIST program of the PHYLIP package (Felsenstein, 1993) with the F84 parameter model, and 
a phylogenetic tree was constructed with the NEIGHBOR program. Statistical significance of groupings was estimated by bootstrapping (1000 replicates) using the programs SEQBOOT, DNADIST, NEIGHBOR and CONSENSE, all of which are from the PHYLIP package. The phylogenetic tree was displayed by using the TREEVIEW program (Page, 1996).

Cell morphologies of the bacteria were observed by phasecontrast microscopy. Determination of Gram reactions was performed using the $\mathrm{KOH}$ method of Gregersen (1978). Sugar-fermentation patterns and aesculin hydrolysis were assessed using the API 50 CHL system (bioMérieux) in duplicate at $37^{\circ} \mathrm{C}$. Lactic acid configuration was determined using a test kit from Boehringer Mannheim. Catalase activity was determined by transferring fresh colonies from MRS agar to a glass slide and adding $5 \% \mathrm{H}_{2} \mathrm{O}_{2}$. The production of gas from glucose was assayed by growing the bacteria in MRS tubes containing Durham tubes. Electrophoretic analysis of whole-cell proteins was performed by the BCCM. The preparation of whole-cell protein extracts and SDS-PAGE analysis were performed as described by Pot et al. (1994). The normalized and digitized patterns were numerically analysed and clustered with reference profiles in the SDS-PAGE protein database of the BCCM. Cell-wall analysis was performed at the DSMZ. Preparation of cell walls and determination of peptidoglycan structure were carried out by the methods described by Schleifer (1985) and Schleifer \& Kandler (1972) with the modification that TLC on cellulose sheets was used instead of paper chromatography. The $\mathrm{G}+\mathrm{C}$ content of the DNA and DNA-DNA relatedness values were determined at the DSMZ. DNA was isolated by chromatography on hydroxyapatite by the procedure of Cashion et al. (1977). The $\mathrm{G}+\mathrm{C}$ content was thereafter determined by HPLC as described by Mesbah et al. (1989) and DNADNA hybridizations were carried out as described by De Ley et al. (1970), with the modifications described by Huß et al. (1983), using a model Cary 100 Bio UV/VISspectrophotometer equipped with a Peltier-controlled $6 \times 6$ multicell changer and a temperature controller with in-situ temperature probe (Varian).

Analysis of the $16 \mathrm{~S}$ rRNA gene sequences of the 15 isolates differing from previously described lactobacilli revealed that they could be divided into four groups. Group G1 contained six isolates from three individuals, G2 contained two isolates from two individuals, G3 contained five isolates from two individuals and G4 contained two isolates from two individuals. Two representative isolates from each group were chosen for further analysis: G1, Kx156A7 ${ }^{\mathrm{T}}$ and Kx293C4; G2, Kx146A4 ${ }^{\mathrm{T}}$ and Kx329A2; G3, Kx127A2 ${ }^{\mathrm{T}}$ and $\mathrm{Kx} 146 \mathrm{C} 2 ; \mathrm{G} 4, \mathrm{Kx}_{146 C 1^{\mathrm{T}}}$ and $\mathrm{Kx} 293 \mathrm{C} 1$.

\section{Group G1}

The complete $16 \mathrm{~S}$ rRNA gene sequence of $\mathrm{Kx} 156 \mathrm{~A} 7^{\mathrm{T}}$ showed the highest levels of similarity to Lactobacillus mucosae, Lactobacillus thermotolerans and Lactobacillus ingluviei, all members of the Lactobacillus reuteri subgroup of lactobacilli, with $96 \cdot 4,95 \cdot 4$ and $95 \cdot 3 \%$ similarity, respectively. A $425 \mathrm{bp}$ sequence from the $16 \mathrm{~S}$ rRNA gene of $\mathrm{Kx} 293 \mathrm{C} 4$ revealed $100 \%$ similarity to that of $\mathrm{Kx} 156 \mathrm{~A} 7^{\mathrm{T}}$. The low level of $16 \mathrm{~S}$ rRNA gene sequence similarity with

Table 1. Some differential characteristics of the species in the L. reuteri subgroup of lactobacilli

Species/strains: 1, L. gastricus sp. nov. Kx156A7 ${ }^{\mathrm{T}}$; 2, L. gastricus sp. nov. Kx293C4; 3, L. antri sp. nov. Kx146A4 ${ }^{\mathrm{T}}$; 4, L. antri sp. nov. Kx329A2; 5, L. coleohominis (data from Nikolaitchouk et al., 2001); 6, L. fermentum (Kandler \& Weiss, 1986); 7, L. frumenti (Müller et al., 2000); 8, L. ingluviei (Baele et al., 2003); 9, L. mucosae (Roos et al., 2000); 10, L. oris (Wiese et al., 1996); 11, L. panis (Wiese et al., 1996); 12, L. pontis (Vogel et al., 1994); 13, L. reuteri (Kandler \& Weiss, 1986); 14, L. thermotolerans (Niamsup et al., 2003); 15, L. vaginalis (Wiese et al., 1996). Symbols:,$+ \geqslant 90 \%$ strains positive;,$- \geqslant 90 \%$ strains negative; d, $11-89 \%$ strains positive; W, weakly positive; NA, no data available.

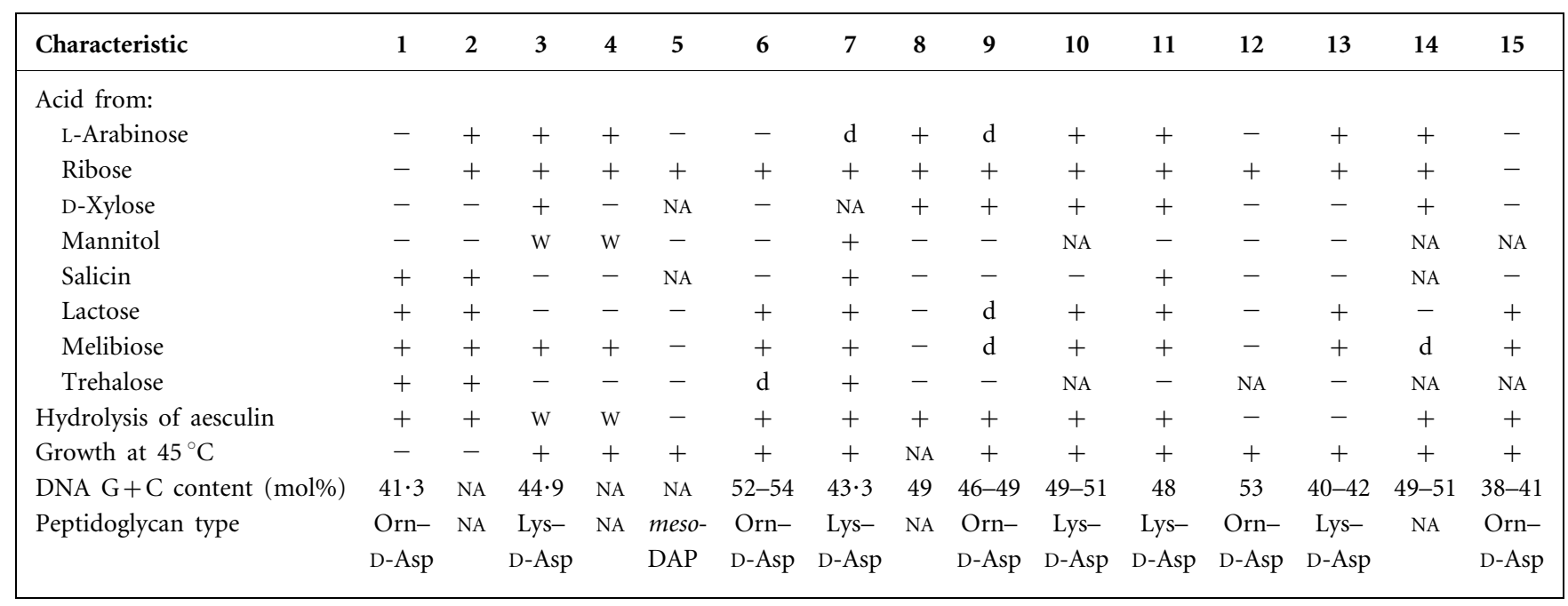




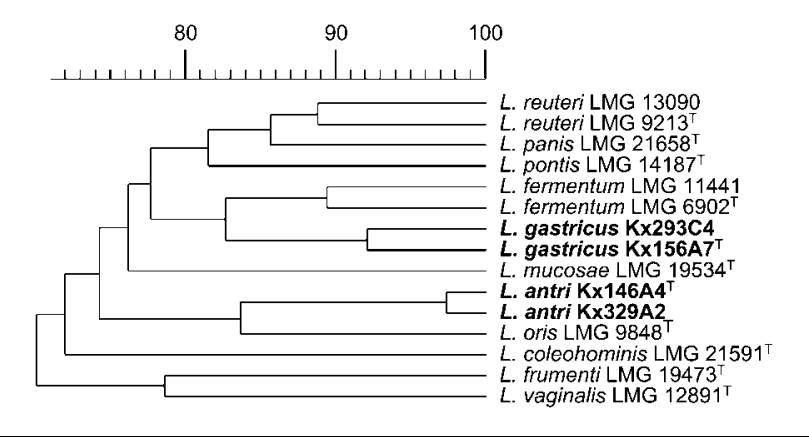

Fig. 1. Dendrogram derived from SDS-PAGE protein pattern analysis of Lactobacillus gastricus sp. nov., Lactobacillus antri $\mathrm{sp}$. nov. and representative strains within the $L$. reuteri subgroup of lactobacilli.

recognized lactobacilli strongly suggests that the isolates in G1 represent a previously undescribed species. Comparison of DNA G $+\mathrm{C}$ content, peptidoglycan type and other characteristics with the members of the $L$. reuteri subgroup (Table 1) confirmed this suggestion. Furthermore, electrophoretic analysis of whole-cell proteins showed that strains $\mathrm{Kx} 156 \mathrm{~A} 7^{\mathrm{T}}$ and $\mathrm{Kx} 293 \mathrm{C} 4$ are distinct from the other species in this subgroup (Fig. 1). We propose that the isolates be classified in the genus Lactobacillus as Lactobacillus gastricus sp. nov. Additional characteristics of strains Kx156A7 ${ }^{\mathrm{T}}$ and $\mathrm{Kx} 293 \mathrm{C} 4$ are given under the species description.

\section{Group G2}

The complete 16S rRNA gene sequence of $\mathrm{Kx} 146 \mathrm{~A} 4^{\mathrm{T}}$ showed the highest levels of similarity to Lactobacillus oris, Lactobacillus panis and Lactobacillus frumenti, all members of the $L$. reuteri subgroup of lactobacilli, with $98 \cdot 8,98 \cdot 0$ and $96.6 \%$ similarity, respectively. A 578 bp sequence from the $16 \mathrm{~S}$ rRNA gene of Kx329A2 showed $100 \%$ similarity to that of $\mathrm{Kx} 146 \mathrm{~A} 4^{\mathrm{T}}$. Owing to the relatively small difference between the sequences of $\mathrm{Kx} 146 \mathrm{~A} 4^{\mathrm{T}}$ and the closest related lactobacilli, DNA-DNA hybridization was performed. Levels of DNA-DNA relatedness between $\mathrm{Kx} 146 \mathrm{~A} 4^{\mathrm{T}}$ and L. oris DSM $4864^{\mathrm{T}}$ and L. panis DSM $6035^{\mathrm{T}}$ were 56 and $59 \%$, respectively. This is clearly below the threshold of $70 \%$ recommended as the lowest value for isolates allocated to the same species (Wayne et al., 1987), indicating that $\mathrm{Kx} 146 \mathrm{~A} 4^{\mathrm{T}}$ represents a novel species. Comparison of DNA G + C content, peptidoglycan type and other characteristics with members of the $L$. reuteri subgroup (Table 1) confirmed this suggestion. Electrophoretic analysis of whole-cell proteins also showed that strains $\mathrm{Kx} 146 \mathrm{~A} 4^{\mathrm{T}}$ and $\mathrm{K} \times 329 \mathrm{~A} 2$ are distinct from the other species in this subgroup (Fig. 1). We propose that the isolates be classified in the genus Lactobacillus as Lactobacillus antri sp. nov. Additional characteristics of strains $\mathrm{Kx} 146 \mathrm{~A} 4^{\mathrm{T}}$ and $\mathrm{Kx} 329 \mathrm{~A} 2$ are given under the species description.

\section{Group G3}

The complete $16 \mathrm{~S}$ rRNA gene sequence of $\mathrm{Kx} 127 \mathrm{~A} 2^{\mathrm{T}}$ showed the highest levels of similarity to Lactobacillus intestinalis, Lactobacillus amylolyticus and Lactobacillus crispatus, all members of the Lactobacillus delbrueckii subgroup of lactobacilli, with $96 \cdot 4,95 \cdot 7$ and $95 \cdot 6 \%$ similarity, respectively. A 518 bp sequence from the $16 \mathrm{~S}$ rRNA gene of $\mathrm{Kx} 146 \mathrm{C} 2$ showed $100 \%$ similarity to that of $\mathrm{Kx} 127 \mathrm{~A} 2^{\mathrm{T}}$. The low levels of $16 \mathrm{~S}$ rRNA gene sequence similarity with recognized lactobacilli strongly suggests that the isolates in G3 represent a previously undescribed species. Comparison of DNA G + C content, peptidoglycan type and other characteristics with the closest related members of the $L$. delbrueckii subgroup (Table 2) confirmed this suggestion. Furthermore, electrophoretic analysis of whole-cell proteins showed that strains $\mathrm{Kx} 127 \mathrm{~A} 2^{\mathrm{T}}$ and $\mathrm{Kx} 146 \mathrm{C} 2$ are distinct from the other species in this subgroup (Fig. 2). We propose that the isolates be classified in the genus Lactobacillus as Lactobacillus kalixensis sp. nov. Additional characteristics of strains $\mathrm{Kx} 127 \mathrm{~A} 2^{\mathrm{T}}$ and $\mathrm{Kx} 146 \mathrm{C} 2$ are given under the species description.

\section{Group G4}

The complete $16 \mathrm{~S}$ rRNA gene sequence of $\mathrm{Kx} 146 \mathrm{Cl}^{\mathrm{T}}$ showed the highest levels of similarity to L. crispatus, Lactobacillus helveticus, Lactobacillus amylovorus and Lactobacillus acidophilus, all members of the L. delbrueckii subgroup of lactobacilli, with $98 \cdot 2,97 \cdot 9,97 \cdot 2$ and $96 \cdot 6 \%$ similarity, respectively. A 560 bp sequence from the $16 \mathrm{~S}$ rRNA gene of $\mathrm{Kx} 293 \mathrm{C} 1$ showed $100 \%$ similarity to that of $\mathrm{Kx} 146 \mathrm{Cl}^{\mathrm{T}}$. Because of the relatively small difference between the sequence of $\mathrm{Kx} 146 \mathrm{C} 1$ and those of the closest related lactobacilli, DNA-DNA hybridization was performed. Levels of DNA-DNA relatedness between $\mathrm{Kx} 146 \mathrm{Cl}^{\mathrm{T}}$ and L. crispatus DSM 20584 ${ }^{\mathrm{T}}$, L. helveticus DSM $20075^{\mathrm{T}}$, L. amylovorus DSM $20531^{\mathrm{T}}$ and L. acidophilus DSM $20079^{\mathrm{T}}$ were 53,54, 40 and $47 \%$, respectively. These are below the threshold of $70 \%$ recommended as the lowest value for isolates allocated to the same species (Wayne et al., 1987), indicating that $\mathrm{Kx} 146 \mathrm{Cl}^{\mathrm{T}}$ represents a previously undescribed species. Comparison of DNA G $+\mathrm{C}$ content, peptidoglycan type and other characteristics with the closest related members of the $L$. delbrueckii subgroup (Table 2) confirmed this suggestion. In addition, electrophoretic analysis of whole-cell proteins showed that strains $\mathrm{Kx} 146 \mathrm{C} 1^{\mathrm{T}}$ and $\mathrm{Kx} 293 \mathrm{C} 1$ are distinct from the other species in this subgroup (Fig. 2). We propose that the isolates be classified in the genus Lactobacillus as Lactobacillus ultunensis sp. nov. Additional characteristics of strains $\mathrm{Kx} 146 \mathrm{C1}^{\mathrm{T}}$ and $\mathrm{Kx} 293 \mathrm{C} 1$ are given under the species description.

The 16S rRNA gene sequences of the four novel species were aligned with those of all members of the L. reuteri subgroup and the most relevant members of the $L$. delbrueckii subgroup. This alignment was then used for a tree analysis. The analysis placed the novel species in 
Table 2. Some differential characteristics of the species in the L. delbrueckii subgroup of lactobacilli

Species/strains: 1, L. kalixensis sp. nov. Kx127A2 ${ }^{\mathrm{T}}$; 2, L. kalixensis sp. nov. Kx146C2; 3, L. ultunensis sp. nov. Kx146C1 ${ }^{\mathrm{T}}$; 4, L. ultunensis sp. nov. Kx293C1; 5, L. acidophilus (data from Kandler \& Weiss, 1986); 6, L. amylolyticus (Bohak et al., 1998); 7, L. amylovorus (Kandler \& Weiss, 1986); 8, L. crispatus (Kandler \& Weiss, 1986); 9, L. delbrueckii subsp. delbrueckii (Kandler \& Weiss, 1986); 10, L. gallinarum (Fujisawa et al., 1992); 11, L. gasseri (Kandler \& Weiss, 1986); 12, L. hamsteri (Hammes et al., 1992); 13, L. helveticus (Kandler \& Weiss, 1986); 14, L. intestinalis (Fujisawa et al., 1990). Symbols:,$+ \geqslant 90 \%$ strains positive;,$- \geqslant 90 \%$ strains negative; d, 11-89\% strains positive; $\mathrm{W}$, weakly positive; NA, no data available.

\begin{tabular}{|c|c|c|c|c|c|c|c|c|c|c|c|c|c|c|}
\hline Characteristic & 1 & 2 & 3 & 4 & 5 & 6 & 7 & 8 & 9 & 10 & 11 & 12 & 13 & 14 \\
\hline \multicolumn{15}{|l|}{ Acid from: } \\
\hline Mannitol & - & + & - & - & - & - & - & - & - & - & - & - & - & + \\
\hline Amygdalin & + & + & - & $\mathrm{W}$ & + & $\mathrm{d}$ & + & + & - & + & + & + & - & - \\
\hline Salicin & + & + & + & + & + & d & + & + & - & + & + & + & - & - \\
\hline Lactose & + & + & + & + & + & - & - & + & - & $\mathrm{d}$ & $\mathrm{d}$ & + & + & $\mathrm{d}$ \\
\hline Melibiose & + & + & - & $\mathrm{w}$ & $\mathrm{d}$ & $\mathrm{d}$ & - & - & - & + & $\mathrm{d}$ & + & + & $\mathrm{d}$ \\
\hline Trehalose & + & + & + & + & d & - & + & - & $\mathrm{d}$ & - & $\mathrm{d}$ & $\mathrm{d}$ & $\mathrm{d}$ & - \\
\hline D-Raffinose & + & + & - & + & d & d & - & - & - & + & $\mathrm{d}$ & + & - & $\mathrm{d}$ \\
\hline Hydrolysis of aesculin & + & + & + & + & + & $\mathrm{d}$ & + & + & - & + & + & NA & - & - \\
\hline DNA G $+C$ content $(\mathrm{mol} \%)$ & $35 \cdot 5$ & NA & $35 \cdot 7$ & NA & $34-37$ & 39 & $40-41$ & $35-38$ & $49-51$ & $36-37$ & $33-35$ & $33-35$ & $38-40$ & $32-35$ \\
\hline Peptidoglycan type & $\begin{array}{l}\text { Lys- } \\
\text { D-Asp }\end{array}$ & $\mathrm{NA}$ & $\begin{array}{l}\text { Lys- } \\
\text { D-Asp }\end{array}$ & $\begin{array}{l}\text { Lys- } \\
\text { D-Asp }\end{array}$ & $\begin{array}{l}\text { Lys- } \\
\text { D-Asp }\end{array}$ & $\begin{array}{l}\text { Lys- } \\
\text { D-Asp }\end{array}$ & $\begin{array}{l}\text { Lys- } \\
\text { D-Asp }\end{array}$ & $\begin{array}{l}\text { Lys- } \\
\text { D-Asp }\end{array}$ & $\begin{array}{l}\text { Lys- } \\
\text { D-Asp }\end{array}$ & NA & $\begin{array}{l}\text { Lys- } \\
\text { D-Asp }\end{array}$ & $\begin{array}{l}\text { Lys- } \\
\text { D-Asp }\end{array}$ & $\begin{array}{l}\text { Lys- } \\
\text { D-Asp }\end{array}$ & NA \\
\hline
\end{tabular}

positions of the phylogenetic tree that correspond to what was found in the similarity rank analyses (Fig. 3).

\section{Description of Lactobacillus gastricus sp. nov.}

Lactobacillus gastricus (gas'tri.cus. N.L. masc. adj. gastricus from Gr. adj. gastrikos of the stomach).

Cells are Gram-positive, non-motile, non-spore-forming, catalase-negative rods, $0.9 \times 1.2 \mu \mathrm{m}$ in size and occurring as single cells or in pairs. After anaerobic growth at $37^{\circ} \mathrm{C}$

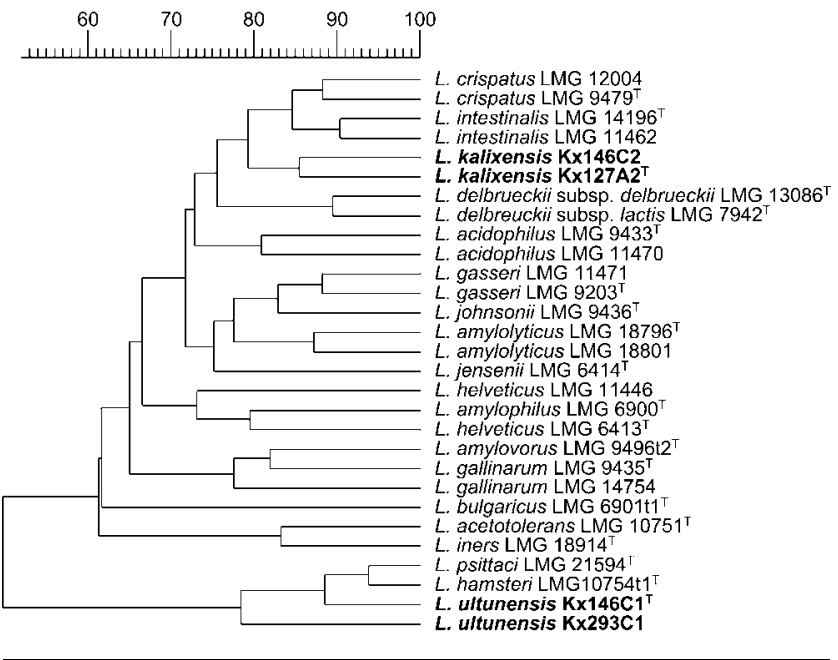

Fig. 2. Dendrogram derived from SDS-PAGE protein pattern analysis of Lactobacillus kalixensis sp. nov., Lactobacillus ultunensis sp. nov. and representative strains within the $L$. delbrueckii subgroup of lactobacilli. for $48 \mathrm{~h}$, colonies on MRS agar are $2 \mathrm{~mm}$ in diameter; they are white, smooth and convex. Growth on MRS agar under aerobic conditions is very weak. In MRS broth, growth occurs at 25 and $42{ }^{\circ} \mathrm{C}$, but not at 20 or $45^{\circ} \mathrm{C}$. Both $\mathrm{D}$ - and L-lactate are produced. Gas is produced from glucose. Acid is produced from L-arabinose (one of two strains), ribose (one of two strains), galactose, D-glucose, D-fructose, D-mannose, methyl $\alpha$-D-glucopyranoside, $N$-acetylglucosamine (one of two strains), amygdalin, arbutin, salicin, cellobiose, maltose, lactose, melibiose, sucrose, trehalose, D-raffinose, $\beta$-gentiobiose, D-turanose and gluconate. Acid is not produced from glycerol, erythritol, $\mathrm{D}$-arabinose, $\mathrm{D}$ xylose, L-xylose, adonitol, methyl $\beta$-D-xyloside, L-sorbose, rhamnose, dulcitol, inositol, mannitol, sorbitol, methyl $\alpha-\mathrm{D}-$ mannoside, inulin, melezitose, starch, glycogen, xylitol, Dlyxose, D-tagatose, D-fucose, L-fucose, D-arabitol, L-arabitol, 2-ketogluconate or 5-ketogluconate. Aesculin is not hydrolysed. The DNA G+C content of strain $\mathrm{Kx} 156 \mathrm{~A} 7^{\mathrm{T}}$ is $41.3 \mathrm{~mol} \%$ and the peptidoglycan type is A4 $\beta$ L-Orn-DAsp. Phylogenetic analysis of the $16 \mathrm{~S}$ rRNA gene sequence places the species in the L. reuteri subgroup of lactobacilli.

The type strain is $\mathrm{Kx}^{156 \mathrm{~A} 7^{\mathrm{T}}}$ (=LMG $22113^{\mathrm{T}}=\mathrm{DSM}$ $16045^{\mathrm{T}}=$ CCUG $48454^{\mathrm{T}}$ ), isolated from a biopsy of the healthy human gastric mucosa.

\section{Description of Lactobacillus antri sp. nov.}

Lactobacillus antri [an'tri. L. gen. n. antri of a cave (the antrum region of the stomach)].

Cells are Gram-positive, non-motile, non-spore-forming, catalase-negative rods, $1 \times 1 \cdot 2-2 \mu \mathrm{m}$ in size and occurring as single cells or in pairs. After anaerobic growth at $37^{\circ} \mathrm{C}$ for $48 \mathrm{~h}$, colonies on MRS agar are $2-3.5 \mathrm{~mm}$ in diameter; 


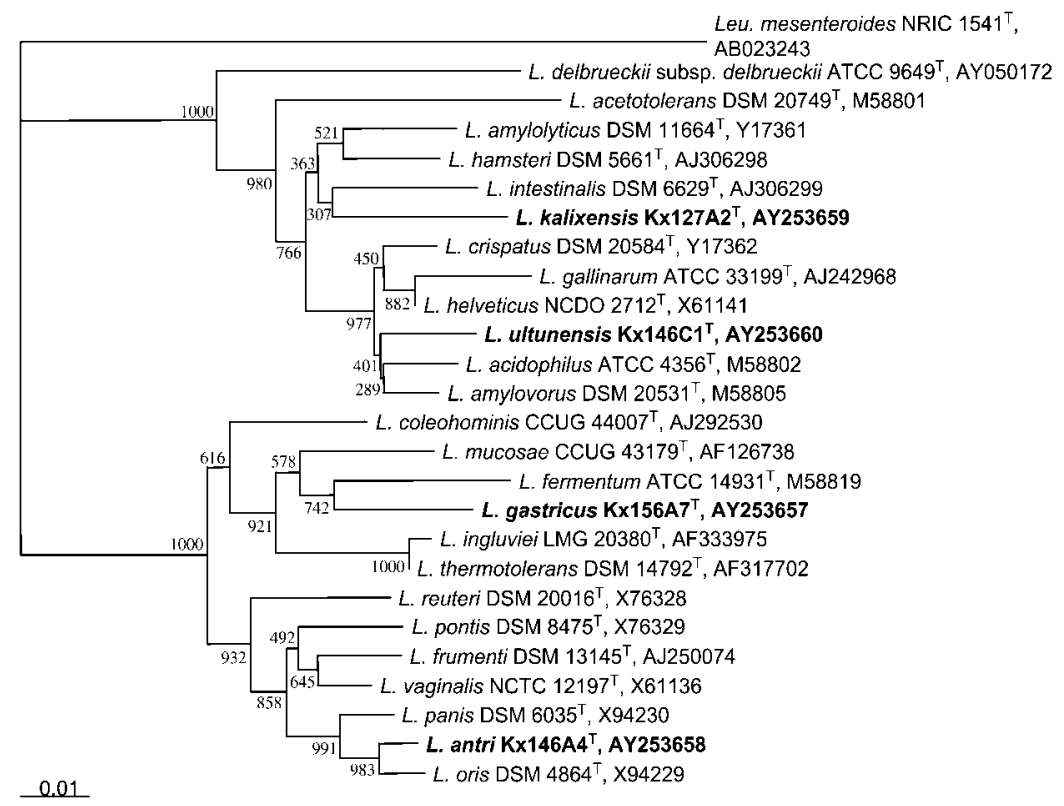

Fig. 3. Unrooted phylogenetic tree derived from 16S rRNA gene sequence analysis showing the relationship of the novel species to members of the Lactobacillus reuteri and $L$. delbrueckii subgroups of lactobacilli. The sequence of Leuconostoc mesenteroides (Leu. mesenteroides) was used as an outgroup representative. Approximately $1500 \mathrm{nt}$ from each sequence were used for the alignment. Bar, $1 \%$ estimated sequence divergence. Numbers indicate bootstrap values for branch points.

they are white, smooth and slightly convex. Growth on MRS agar under aerobic conditions is very weak. In MRS broth, growth occurs at 25 and $45^{\circ} \mathrm{C}$, but not $20^{\circ} \mathrm{C}$. Both $\mathrm{D}$ - and L-lactate are produced. Gas is produced from glucose. Acid is produced from L-arabinose, ribose, D-xylose (one of two strains), galactose, D-glucose, D-fructose, mannitol (weak reaction), methyl $\alpha$-D-glucopyranoside (weak reaction), maltose, melibiose, sucrose, D-raffinose, D-turanose (weak reaction), D-arabitol and gluconate (weak reaction). Acid is not produced from glycerol, erythritol, D-arabinose, L-xylose, adonitol, methyl $\beta$-D-xyloside, D-mannose, L-sorbose, rhamnose, dulcitol, inositol, sorbitol, methyl $\alpha$-D-mannoside, $N$-acetylglucosamine, amygdalin, arbutin, salicin, cellobiose, lactose, trehalose, inulin, melezitose, starch, glycogen, xylitol, $\beta$-gentiobiose, D-lyxose, D-tagatose, D-fucose, L-fucose, L-arabitol, 2ketogluconate or 5-ketogluconate. Aesculin is hydrolysed (weak reaction). The DNA $\mathrm{G}+\mathrm{C}$ content of strain $\mathrm{Kx} 146 \mathrm{~A} 4^{\mathrm{T}}$ is $44.9 \mathrm{~mol} \%$ and the peptidoglycan type is A $4 \alpha$ L-Lys-D-Asp. Phylogenetic analysis of the 16S rRNA gene sequence places the species in the L. reuteri subgroup of lactobacilli.

The type strain is $\mathrm{Kx} 146 \mathrm{~A} 4^{\mathrm{T}}$ (=LMG $22111^{\mathrm{T}}=\mathrm{DSM}$ $16041^{\mathrm{T}}=$ CCUG $48456^{\mathrm{T}}$ ), isolated from a biopsy of the healthy human gastric mucosa.

\section{Description of Lactobacillus kalixensis sp. nov.}

Lactobacillus kalixensis (ka.lix.en'sis. N.L. masc. adj. kalixensis pertaining to Kalix, a town in northern Sweden, where the gastric biopsies were sampled).

Cells are Gram-positive, non-motile, non-spore-forming, catalase-negative rods, $1 \times 1 \cdot 5-10 \mu \mathrm{m}$ in size and occurring as single cells, pairs or chains. After anaerobic growth at $37^{\circ} \mathrm{C}$ for $48 \mathrm{~h}$, colonies on MRS agar are $2 \mathrm{~mm}$ in diameter; they are white, smooth and convex. Growth on MRS agar under aerobic conditions is weak. In MRS broth, growth occurs at 25 and $45^{\circ} \mathrm{C}$, but not at $20^{\circ} \mathrm{C}$. Both D- and Llactate are produced. Gas is not produced from glucose. Acid is produced from galactose, D-glucose, D-fructose, D-mannose, mannitol (one of two strains), $\mathrm{N}$-acetylglucosamine, amygdalin, arbutin, salicin, cellobiose, maltose, lactose, melibiose, sucrose, trehalose, D-raffinose, starch and $\beta$-gentiobiose. Acid is not produced from glycerol, erythritol, D-arabinose, L-arabinose, ribose, D-xylose, L-xylose, adonitol, methyl $\beta$-D-xyloside, L-sorbose, rhamnose, dulcitol, inositol, sorbitol, methyl $\alpha$-D-mannoside, methyl $\alpha$-D-glucopyranoside, inulin, melezitose, glycogen, xylitol, D-turanose, D-lyxose, D-tagatose, D-fucose, L-fucose, D-arabitol, L-arabitol, gluconate, 2-ketogluconate or 5ketogluconate. Aesculin is hydrolysed. The DNA G+C content of strain $\mathrm{Kx} 127 \mathrm{~A} 2^{\mathrm{T}}$ is $35.5 \mathrm{~mol} \%$ and the peptidoglycan type is A $4 \alpha$ L-Lys-D-Asp. Phylogenetic analysis of the 16S rRNA gene sequence places the species in the $L$. delbrueckii subgroup of lactobacilli.

The type strain is $\mathrm{Kx} 127 \mathrm{~A} 2^{\mathrm{T}}$ (=LMG $22115^{\mathrm{T}}=\mathrm{DSM}$ $16043^{\mathrm{T}}=$ CCUG $48459^{\mathrm{T}}$ ), isolated from a biopsy of the healthy human gastric mucosa.

\section{Description of Lactobacillus ultunensis sp. nov.}

Lactobacillus ultunensis (ul.tun.en'sis. N.L. masc. adj. ultunensis pertaining to Ultuna, the site of Swedish University of Agricultural Sciences in Uppsala, Sweden).

Cells are Gram-positive, non-motile, non-spore-forming, catalase-negative rods, $1 \times 2-30 \mu \mathrm{m}$ in size and occurring as single cells, pairs or filaments. After anaerobic growth at $37^{\circ} \mathrm{C}$ for $48 \mathrm{~h}$, colonies on MRS agar are $2-3 \mathrm{~mm}$ in diameter; they are white, irregular and have a dry appearance. Growth on MRS agar under aerobic conditions is 
very weak. In MRS broth, growth occurs at 25 and $42{ }^{\circ} \mathrm{C}$, but not at 20 or $45^{\circ} \mathrm{C}$. Both D- and L-lactate are produced. Gas is not produced from glucose. Acid is produced from galactose, D-glucose, D-fructose, D-mannose, $\mathrm{N}$ acetylglucosamine, arbutin, salicin, cellobiose, maltose, lactose, melibiose (one of two strains, weak reaction), sucrose, trehalose, D-raffinose (one of two strains), starch (one of two strains) and $\beta$-gentiobiose. Acid is not produced from glycerol, erythritol, D-arabinose, L-arabinose, ribose, D-xylose, L-xylose, adonitol, methyl $\beta$-D-xyloside, L-sorbose, rhamnose, dulcitol, inositol, mannitol, sorbitol, methyl $\alpha$-D-mannoside, methyl $\alpha$-D-glucopyranoside, amygdalin, inulin, melezitose, glycogen, xylitol, D-turanose, Dlyxose, D-tagatose, D-fucose, L-fucose, D-arabitol, L-arabitol, gluconate, 2-ketogluconate or 5-ketogluconate. Aesculin is hydrolysed. The DNA G $+\mathrm{C}$ content of strain $\mathrm{Kx} 146 \mathrm{C} 1^{\mathrm{T}}$ is $35.7 \mathrm{~mol} \%$ and the peptidoglycan type is A $4 \alpha$ L-Lys-D-Asp. Phylogenetic analysis of the $16 \mathrm{~S}$ rRNA gene sequence places the species in the L. delbrueckii subgroup of lactobacilli.

The type strain is $\mathrm{Kx} 146 \mathrm{Cl}^{\mathrm{T}}$ (=LMG $22117^{\mathrm{T}}=\mathrm{DSM}$ $16047^{\mathrm{T}}=$ CCUG $48460^{\mathrm{T}}$ ), isolated from a biopsy of the healthy human gastric mucosa.

\section{Acknowledgements}

We thank Professor Hans G. Trüper, Institut für Mikrobiologie \& Biotechnologie, Rheinische Friedrich-Wilhelms-Universität, Bonn, Germany, and Dr Jean Euzéby, Laboratoire de Bactériologie, École Nationale Vétérinaire, Toulouse, France, for advice regarding nomenclature; Dr Marc Vancanneyt, BCCM, Gent University, Gent, Belgium, for construction of the protein profile dendrograms; Karin Wreiber, Swedish Institute for Infectious Disease Control, for assistance with isolation of the bacteria; and Cecilia Berglund, Swedish University of Agricultural Sciences, for assistance with characterization of the bacteria.

\section{References}

Baele, M., Vancanneyt, M., Devriese, L. A., Lefebvre, K., Swings, J. \& Haesebrouck, F. (2003). Lactobacillus ingluviei sp. nov., isolated from the intestinal tract of pigeons. Int J Syst Evol Microbiol 53, 133-136.

Bohak, I., Back, W., Richter, L., Ehrmann, M., Ludwig, W. \& Schleifer, K. H. (1998). Lactobacillus amylolyticus sp. nov., isolated from beer malt and beer wort. Syst Appl Microbiol 21, 360-364.

Cashion, P., Holder-Franklin, M. A., McCully, J. \& Franklin, M. (1977). A rapid method for the base ratio determination of bacterial DNA. Anal Biochem 81, 461-466.

De Ley, J., Cattoir, H. \& Reynaerts, A. (1970). The quantitative measurement of DNA hybridization from renaturation rates. Eur J Biochem 12, 133-142.

Felsenstein, J. (1993). PHYLIP (Phylogeny Inference Package), version 3.5c. Distributed by the author. Department of Genetics, University of Washington, Seattle, USA.

Fujisawa, T., Itoh, K., Benno, Y. \& Mitsuoka, T. (1990). Lactobacillus intestinalis (ex Hemme 1974) sp. nov., nom. rev., isolated from the intestines of mice and rats. Int J Syst Bacteriol 40, 302-304.

Fujisawa, T., Benno, Y., Yaeshima, T. \& Mitsuoka, T. (1992). Taxonomic study of the Lactobacillus acidophilus group, with recognition of Lactobacillus gallinarum sp. nov. and Lactobacillus johnsonii sp. nov. and synonymy of Lactobacillus acidophilus group A3 (Johnson et al. 1980) with the type strain of Lactobacillus amylovorus (Nakamura 1981). Int J Syst Bacteriol 42, 487-491.

Gregersen, T. (1978). A rapid method for distinction of Gramnegative from Gram-positive bacteria. Eur $J$ Appl Microbiol Biotechnol 5, 123-127.

Hammes, W. P., Weiss, N. \& Holzapfel, W. (1992). The genera Lactobacillus and Carnobacterium. In The Prokaryotes, 2nd edn, pp. 1535-1594. Edited by A. Balows, H. G. Trüper, M. Dworkin, W. Harder \& K.-H. Schleifer. Springer: New York.

Huß, V. A. R., Festl, H. \& Schleifer, K. H. (1983). Studies on the spectrophotometric determination of DNA hybridization from renaturation rates. Syst Appl Microbiol 4, 184-192.

Kandler, O. \& Weiss, N. (1986). Genus Lactobacillus Beijerinck 1901, 212 ${ }^{\mathrm{AL}}$. In Bergey's Manual of Systematic Bacteriology, vol. 2, pp. 1209-1234. Edited by P. H. A. Sneath, N. S. Mair, M. E. Sharpe \& J. G. Holt. Baltimore: Williams \& Wilkins.

Mesbah, M., Premachandran, U. \& Whitman, W. B. (1989). Precise measurement of the $\mathrm{G}+\mathrm{C}$ content of deoxyribonucleic acid by highperformance liquid chromatography. Int J Syst Bacteriol 39, 159-167.

Müller, M. R. A., Ehrmann, M. A. \& Vogel, R. F. (2000). Lactobacillus frumenti sp. nov., a new lactic acid bacterium isolated from rye-bran fermentations with a long fermentation period. Int J Syst Evol Microbiol 50, 2127-2133.

Niamsup, P., Sujaya, I. N., Tanaka, M. \& 8 other authors (2003). Lactobacillus thermotolerans sp. nov., a novel thermotolerant species isolated from chicken faeces. Int J Syst Evol Microbiol 53, 263-268.

Nikolaitchouk, N., Wacher, C., Falsen, E., Andersch, B., Collins, M. D. \& Lawson, P. A. (2001). Lactobacillus coleohominis sp. nov., isolated from human sources. Int J Syst Evol Microbiol 51, 2081-2085.

Page, R. D. M. (1996). TREEVIEW: an application to display phylogenetic trees on personal computers. Comput Appl Biosci 12, 357-358.

Pot, B., Vandamme, P. \& Kersters, K. (1994). Analysis of electrophoretic whole-organism protein fingerprints. In Chemical Methods in Prokaryotic Systematics, pp. 493-521. Edited by M. Goodfellow \& A. G. O'Donnell. Chichester: Wiley.

Roos, S., Karner, F., Axelsson, L. \& Jonsson, H. (2000). Lactobacillus mucosae sp. nov., a new species with in vitro mucus-binding activity isolated from pig intestine. Int J Syst Evol Microbiol 50, 251-258.

Schleifer, K. H. (1985). Analysis of the chemical composition and primary structure of murein. Methods Microbiol 18, 123-156.

Schleifer, K. H. \& Kandler, O. (1972). Peptidoglycan types of bacterial cell walls and their taxonomic implications. Bacteriol Rev 36, 407-477.

Thompson, J. D., Higgins, D. G. \& Gibson, T. J. (1994). CLUSTAL W: improving the sensitivity of progressive multiple sequence alignment through sequence weighting, position-specific gap penalties and weight matrix choice. Nucleic Acids Res 22, 4673-4680.

Vogel, R. F., Böcker, G., Stolz, P. \& 7 other authors (1994). Identification of lactobacilli from sourdough and description of Lactobacillus pontis sp. nov. Int J Syst Bacteriol 44, 223-229.

Wayne, L. G., Brenner, D. J., Colwell, R. R. \& 9 other authors (1987). Report of the ad hoc committee on reconciliation of approaches to bacterial systematics. Int J Syst Bacteriol 37, 463-464.

Weizenegger, M., Neumann, M., Stackebrandt, E., Weiss, N. \& Ludwig, W. (1992). Eubacterium alactolyticum phylogenetically groups with Eubacterium limosum, Acetobactericum woodii and Clostridum barkeri. Syst Appl Microbiol 15, 32-36.

Wiese, B. G., Strohmar, W., Rainey, F. A. \& Diekmann, H. (1996). Lactobacillus panis sp. nov., from sourdough with a long fermentation period. Int J Syst Bacteriol 46, 449-453. 